\title{
Proses Pembuatan Akta Jaminan Fidusia Menggunakan Kendaraan Bermotor Yang Masih Dalam Proses Inden Sebagai Jaminannya
}

\author{
Raymond Bagus Nurchandra1, Retno Murni ${ }^{2}$
}

${ }^{1}$ Fakultas Hukum Universitas Udayana, E-mail: timeforfuns27@yahoo.com

2Fakultas Hukum Universitas Udayana, E-mail: retnomurni@unud.ac.id

\begin{abstract}
Info Artikel
Masuk : 21 November 2020

Diterima : 22 November 2020

Terbit : 1 April 2021

Keywords :

Fiduciary Deed, Motor Vehicle,

Pivot

Kata kunci:

Akta Jaminan fidusia,

Kendaraan Bermotor, Inden

Corresponding Author:

Raymond bagus Nurchandra,

E-mail: timeforfuns27@yahoo.com

DOI :

10.24843/AC.2021.v06.i01.p14
\end{abstract}

\begin{abstract}
The purpose of this research is to determine the validity of a fiduciary security deed using a motorized vehicle that is still in the indent process as a guarantee. This type of research is empirical legal research which is based on primary data sources and secondary data sources. Then the conclusions are drawn through descriptive analysis techniques. The results show that a motorized vehicle that is still in the pivoting process can be charged with a fiduciary guarantee, but the debtor must attach proof of the order given by the dealer The part that will pay the vehicle in full to the dealer is the bank and after the proof of payment is given in full, the proof must be presented in front of a notary. The debtor must also make his own statement if the BPKB has been issued, it must be immediately submitted to the bank. The validity of a fiduciary guarantee deed that uses a motorized vehicle that is still in the pivot process as evidence is legally recognized because in the provisions of the explanation of article 6 letter $c$ of the Law on Fiduciary Security does not clearly emphasize the existence of BPKB ownership so that proof of purchase orders can already be obtained. used as proof of ownership of a motorized vehicle that is still in the process of being indented.
\end{abstract}


menggunakan kendaran bermotor yang masih dalam proses inden sebagai alat bukti diakui sah secara hukum karena didalam ketentuan penjelasan Pasal 6 huruf c Undang-Undang tentang Jaminan Fidusia tidak menekankan secara jelas harus adanya kepemilikan BPKB sehingga bukti purchase order saja sudah dapat digunakan sebagai suatu bukti kepemilikan kendaraan bermotor yang masih dalam proses inden.

\section{Pendahuluan}

Lembaga jaminan fidusia merupakan suatu bentuk lembaga jaminan yang banyak diminati dikarenakan lembaga jaminan fidusia merupakan jaminan terhadap benda yang bergerak seperti kendaraan bermotor. Lembaga jaminan fidusia telah diatur didalam suatu peraturan perundang - undangan yaitu Undang - Undang Nomor 42 tahun 1999 (untuk selanjutnya disebut dengan UU Jaminan Fidusia). Terhadap jaminan yang diikat dengan jaminan fidusia maka harus menaati ketentuan peraturan perundang - undangan. ${ }^{1}$ Setelah diundangkannya UU Jaminan Fidusia mengakibatkan perlunya suatu pendaftaran jaminan fidusia sesuai yang diatur dalam ketentuan pasal 11 UU Jaminan Fidusia agar dapat memberikan suatu kepastian hukum bagi pihak yang terlibat.

Tahapan pendaftaran jaminan fidusia diawali dengan dibuatnya suatu akta jaminan fidusia kedalam bentuk akta autentik yang dibuat dihadapan pihak notaris sesuai dengan ketetuan Pasal 5 ayat (1) UU Jaminan Fidusia dan dilanjutkan dengan pendaftaran pada kantor pendaftaran fidusia. Akta jaminan fidusia yang dibuat dalam bentuk autentik dipilih agar akta tersebut nantinya dapat memberi perlindungan hukum bagi pihak yang terkait dan adanya campur tangan notaris selaku penasehat hukum untuk para pihak, nasehat hukum yang disampaikan oleh notaris bertujuan untuk menyadarkan para pihak mengenai akibat hukum yang mungkin ada dari perbuatan yang melawan hukum. ${ }^{2}$ Seorang notaris memiliki suatu peranan didalam hal pemberian nasihat hukum terhadap para pihak mengenai permasalahan yang ada yang kemudian dituangkan pada akta yang berkaitan sesuai dengan kemauan maupun keterangan yang disampaikan oleh para pihak yang berkaitan, dan bukan merupakan keterangan dari pihak notaris. ${ }^{3}$

Suatu kendaraan bermotor yang dibebankan dengan jaminan fidusia maka hak kepemilikan atas kendaraan bermotor tersebut akan beralih kepihak kreditor dan fisik kendaraan bermotor tersebut masih bisa dikuasai oleh pihak debitor. Suatu kendaraan bermotor yang dibebankan dengan jaminan fidusia maka hal terpenting yang harus diketahui oleh Bank selaku pihak kreditor adalah jenis dari kendaraan yang dibebankan jaminan fidusia tersebut. Jika kendaraan yang dibebankan adalah kendaraan roda empat maka harus diketahui apakah kendaraan tersebut tergolong

\footnotetext{
${ }^{1}$ Widyari, I. A. M., Sirtha, I. N., \& Sarjana, I. M. (2017). Akibat Hukum Pendaftaran Jaminan Fidusia Dalam Sistem Online. Acta Comitas: Jurnal Hukum Kenotariatan, 2(2), 268-276. h. 2

2 Ibid, h. 190

${ }^{3}$ Habib Adjie, (2008). Hukum Notaris Indonesia (Tafsir Telematik Terhadap UU Nomor 30 Tentang Jabatan Notaris). Jakarta. Refika Aditama, h. 4
} 
sebagai kendaraan umum, kendaraan pribadi ataupun sebuah truk. Perlunya pihak kreditor mengetahui hal tersebut dikarenakan beberapa kendaraan roda empat memiliki suatu izin yang mengkhusus untuk dapat beroprasi yang dikeluarkan oleh pihak yang memang berwenang. ${ }^{4}$

Kendaraan bermotor yang dibebankan dengan jaminan fidusia maka bukti kepemilikan kendaraan bermotor itu dipegang oleh pihak bank selaku kreditor sebagai suatu upaya perlindungan hukum bagi pihak debitor. Saat pihak debitor belum dapat membayar lunas utang yang dimilikinya atau melakukan suatu wanprestasi maka saat itu pula pihak kreditor akan memiliki suatu hak untuk dapat menjual benda bergerak yang dijaminkan padanya untuk dapat memperoleh pelunasan piutang yang dimiliki oleh pihak kreditor. Pihak debitor telah mampu membayar lunas utang yang dimilikinya maka benda yang dijaminkan kepada pihak kreditor akan dilakukan penyerahan untuk dikembalikan lagi kepada pemiliknya yaitu pihak debitor. ${ }^{5}$

Pada dasarnya seseorang yang ingin membebankan kendaraan bermotor yang dimilikinya dengan jaminan fidusia harus menunjukan bukti kepemilikan kendaraan bermotor (untuk selanjutnya disebut dengan BPKB). Sedangkan dalam prakteknya dapat dilihat suatu kendaraan bermotor yang masih dalam proses inden bisa dibebankan dengan jaminan fidusia. Inden menurut Kamus Besar Bahasa Indonesia diartikan yaitu suatu pembelian terhadap barang yang dilakukan dengan cara memasan serta melakukan pembayaran terlebih dahulu. ${ }^{6}$ Berdasarkan pengertian itu disebutkan bahwa barang inden diartikan sebagai barang yang telah dipesan oleh pihak pembeli pada saat itu belum ada ataupun barang sudah ada namun belum didalam penguasaan pihak penjual. Terhadap inden dapat pula diartikan sebagai suatu bentuk janji untuk dapat terjadinya suatu jual beli kemudian hari.

Bedasarkan ketentuan pada penjelasan Pasal 6 huruf c UU Jaminan Fidusia yang hanya menentukan mengenai benda yang menjadi obyek jaminan fidusia hanya perlu dilakukan identifikasi dan dijelaskan dengan hanya surat bukti kepemilikannya saja yang tidak dijelaskan perlunya kepemilikan BPKB. Mengenai kendaraan bermotor yang masih dalam proses inden yang dibebankan dengan jaminan fidusia maka pihak atau lembaga penyedia kredit yang dalam hal ini adalah pihak Bank yang akan bertanggung jawab atas pelunasan pembayaran kendaraan bermotor tersebut. Pihak Bank akan melampirkan bukti pemesanan kendaraan bermotor tersebut atau biasa disebut dengan purchase order yang diberikan oleh pihak dealer kepada pihak notaris. Saat telah dilakukan pembayaran lunas oleh pihak bank terhadap kendaraan bermotor tersebut maka surat pembayaran lunas atas kendaraan bermotor tersebut harus dipaparkan dihadapan pihak notaris. Hal tersebut menjelaskan bahwa purchase order dapat digunakan sebagai tanda kepemilikan atas kendaraan bermotor tersebut yang didalamnya berisi data diri pembeli kendaraan bermotor sesuai Kartu Tanda Penduduk (KTP) sehingga kendaraan bermotor yang masih dalam proses inden dapat dibebankan dengan jaminan fidusia namun harus disesuaikan dengan prosedur yang

\footnotetext{
${ }^{4}$ Kumaladewi, N. A. (2015). Eksekusi Kendaraan Bermotor Sebagai Jaminan Fidusia yang Berada Pada Pihak Ketiga. Repertorium, 2(2). h. 61

${ }^{5}$ Rachmadi Usman. (2009). Hukum Jaminan Keperdataan. Jakarta. Sinar Grafika, h. 153

${ }^{6}$ Poerwadarminta W.J.S. (2007). Kamus Umum Bahasa Indonesia. Jakarta. PN. Balai Pustaka. h. 145
} 
telah ditetapkan. Berdasarkan pemaparan yang telah disampaikan diatas, maka penting untuk dilakukannya suatu penelitian mengenai : Bagaimanakah proses pembuatan suatu akta jaminan fidusia terhadap kendaraan bermotor yang masih dalam proses inden ?, dan Bagaimankah keabsahan dari suatu akta jamian fidusia yang menggunakan kendaraan bermotor yang masih dalam proses inden sebagai jaminan?

Penulisan ini bertujuan untuk mengetahui proses didalam pembuatan akta jaminan fidusia yang menggunakan kendaraan bermotor yang masih dalam proses inden sebagai jaminannya dan untuk mengetahui keabsahan dari suatu akta jaminan fidusia yang menggunakan kendaraan bermotor yang masih dalam proses inden sebagai jaminannya.

Setelah melakukan penelusuran, terdapat beberapa judul artikel yang memiliki kemiripan dengan penelitian ini, yaitu artikel yang berjudul "Implementasi Jaminan Fidusia Dalam Pemberian Kredit Di Indonesia" oleh Fatma Paparang, dengan rumusan masalah : (1) Bagaimanakah implementasi pengaturan tentang jaminan fidusia dalam praktek khususnya terkait praktek pemberian kredit melalui bank? dan (2) Kendala - kendala apa yang ditemukan dalam implementasi jaminan fidusia terkait dengan proses pemberian kredit ?7 dan Jurnal yang berjudul "Aspek Hukum Pendaftaran Jaminan Fidusia Berdasarkan Undang - Undang Nomor 42 Tahun 1999 Tentang Jaminan Fidusia" oleh Nur Hayati, dengan rumusan masalah : (1) Bagaimana jaminan fidusia dapat memberikan perlindungan hukum bagi kreditur menurut UU No 42 tahun 1999 tentang jaminan fidusia?.8 Berdasarkan uraian diatas maka terdapat perbedaan antara penelitian yang terdahulu dengan penelitian yang dilakukan oleh penulis. Penelitian yang penulis fokuskan yaitu membahas pada proses pembuatan suatu akta jaminan fidusia menggunakan kendaraan bermotor yang masih dalam proses inden sebagai jaminannya.

\section{Metode Penelitian}

Penulisan artikel ini menggunakan jenis penelitian hukum empiris. Penelitian hukum empiris ialah penelitian yang dapat dilihat didalam kehidupan nyata. Penelitian hukum, empiris dilakukan dengan cara meneliti data sekunder saat awal penelitian dilakukan serta dilanjutkannya dengan cara meneliti suatu data primer di lapangan yaitu responden yang berasal dari pihak masyarakat secara langsung. ${ }^{9}$ Suatu data primer diterima dari suatu sumber yang pertama. Data sekunder itu diperoleh melalui bahan - bahan kepustakaan, arsip- arsip maupun dokumen-dokumen yang terdiri dari bahan hukum primer yaitu, Undang - Undang Nomor 2 Tahun 2014 tentang Perubahan atas Undang - Undang Nomor 30 Tahun 2004 tentang Jabatan Notaris dan Undang - Undang Nomor Nomor 42 Tahun 1999 tentang Jaminan Fidusia dan bahan hukum sekunder yaitu karya ilmiah, hasil penelitian terdahulu dan hasil karya dari praktisi hukum dan sejenisnya. Data yang ada dalam penelitian ini dikumpulkan

\footnotetext{
${ }^{7}$ Paparang, F. (2014). Implementasi Jaminan Fidusia Dalam Pemberian Kredit Di Indonesia. Jurnal LPPM Bidang EkoSosBudKum, 1(2), 56-70. h. 58

${ }^{8}$ Hayati, N. (2016). Aspek Hukum Pendaftaran Jaminan Fidusia Berdasarkan Undang-Undang Nomor 42 Tahun 1999 Tentang Jaminan Fidusia. Lex Jurnalica, 13(2), 147577, h. 2

9 Soerjono Soekanto. (2012). Pengantar penelitian Hukum. Jakarta: UI Press. h .52
} 
melalui menelaah kepustakaan terhadap bahan - bahan hukum serta juga melalui wawancara yang mana dilakukan secara langsung dengan cara memberikan beberapa pertanyaan pada para informan yang memang memiliki suatu kewenangan yang terkait dengan permasalahan agar mendapat suatu jawaban yang relevan. Setelah semua data - data terkumpul maka akan dilakukannya analisis secara deskriptif serta didukungnya dengan metode kualitatif agar bisa mendapatkan suatu kesimpulan yang memang tepat.

\section{Hasil Dan Pembahasan \\ 3.1 Proses Pembuatan Suatu Akta Jaminan Fidusia Terhadap Kendaraan Bermotor Yang Masih Dalam Proses Inden}

Pengertian jaminan fidusia diatur didalam ketentuan Pasal 1 ayat (2) UU Jaminan Fidusia yang menentukan jaminan fidusia merupakan suatu hak jaminan terhadap suatu benda yang bergerak yang berwujud ataupun yang tidak berwujud serta terhadap benda yang tidak bergerak seperti suatu bangunan yang tidak bisa untuk dibebankan dengan suatu hak tanggungan yang mana benda tersebut masih didalam penguasaan pihak pemberi fidusia, yang merupakan agunan terhadap suatu pelunasaan utang serta memberikan kedudukan yang mana lebih diutamakan terhadap pihak penerima fidusia dibandingkan dengan pihak kreditor lainnya. Suatu keistimewaan yang dapat dilihat dalam jaminan fidusia tersebut adalah adanya penyerahan dari suatu hak milik atas dasar kepercayaan terhadap benda milik pihak debitor kepada pihak kreditor yangmana benda secara fisiknya masih dapat dikuasai oleh pihak debitornya. Keuntungan lain yang juga dirasakan bagi pihak debitor dengan adanya lembaga jaminan fidusia ini yaitu masih dapat digunakannya benda yang sudah dibebankan jaminan fidusia yangmana tidak akan terganggunya kegiatan usaha milik debitor serta adanya keamanan maupun kepastian hukum terhadap pihak debitor. 10

Menurut ketentuan yang ada pada Pasal 1870 KUHPerdata yang menentukan bahwa perjanjian fidusia harus dibuat dalam bentuk suatu akta otentik yang dibuat dihadapan notaris. Perjanjian fidusia antar para pihak dituangkan kedalam bentuk akta jaminan fidusia yang dibuat dalam bentuk akta otentik agar akta tersebut memiliki kekuatan pembuktian yang sempurna mengenai hal yang dimuat dalam akta tersebut. Pada praktek dapat dilihat benda bergerak yang dibebankan dengan jaminan fidusia adalah benda bergerak yang tidak terdaftar sehingga bentuk akta otentik dianggap bisa memberikan suatu jaminan dalam hal kepastian hukum terkait objek pada jaminan fidusia itu. Suatu akta jaminan fidusia yang dibuat maka didalamnya akan terdapat suatu kesepakatan tertentu antara pihak debitor dan kreditor yang memberikan suatu keistimewaan terhadap pihak kreditor yang berupa kedudukan yang lebih kuat terhadap pihak kreditor setelah didaftarkan. Pendaftaran tersebut meliputi pendaftaran terhadap benda yang digunakan sebagai ikatan dalam jaminan fidusia tersebut. Kesepakatan - kesepakatan yang tertuang didalam akta jaminan fidusia berlaku serta dapat mengikat pihak ketiga. ${ }^{11}$ Suatu benda yang dibebankan

\footnotetext{
10 Sri Hartini. (2008). Pelaksanaan Perjanjian Kredit Dengan Jaminan Fidusia Di Kantor Pusat PT Bank Bukopin Tbk Jakarta (Tesis Program Magister Kenotariatan Universitas Diponegoro, h. 42) 11 Winarno, J. (2013). Perlindungan Hukum bagi Kreditur pada Perjanjian Jaminan Fidusia. Jurnal Independent, 1(1). h. 52
} 
dengan jaminan fidusia harus didaftarakan ditempat dimana kedudukan dari pihak debitor atau pemberi fidusia. Tujuan didaftarkannya benda yang dibebani dengan jaminan fidusia tersebut adalah agar terpenuhinya asas publisitas serta sebagai suatu jaminan untuk memberikan kepastian terhadap pihak kreditor terhadap benda yang dibebani dengan jaminan fidusia tersebut. ${ }^{12}$

Syarat didalam pembuatan suatu akta jamianan fidusia yang menggunakan kendaraan bermotor yang masih didalam proses inden sebagai jaminan sama seperti syarat yang diperlukan didalam pembuatan akta jaminan fidusia biasa. Pihak debitor yang hadir didalam pembuatan akta jaminan fidusia nama pihak debitor harus sesuai dengan nama yang tertera didalam Kartu Tanda Penduduk milik debitor. Terhadap kendaraan bermotor yang masih dalam proses inden yang dibebankan dengan jaminan fidusia maka nama pihak debitor yang tertera didalam bukti pemesanan harus sesuai dengan nama yang tertera didalam Kartu Tanda Penduduk (KTP) Milik Debitor. Dalam akta jaminan fidusia yang dibuat harus dicantumkan secara jelas mengenai Jenis kendaraan bermotor yang dibebankan dengan jaminan fidusia, jumlah kendaraan bermotor yang dibebankan jaminan fidusia, nilai dari kendaraan bermotor yang dibankan jaminan fidusia, nomor serta tanggal kepemilikan kendaraan bermotor tersebut yang bisa berupa fakyur maupun suatu kwitansi jual beli, nomor serta tanggal akta pengikatan tersebut. Selain hal tersebut terhadap bukti dari kepemilikan kendaraan bermotor bermotor tersebut diserahkan serta dikuasai oleh pihak Bank untuk mencegah perbuatan dari pihak debitor yang ingin menjaminkan kembali kendaraan bermotor yang sudah dijadikan jaminan kepada pada bank lain. ${ }^{13}$

Berdasarkan hasil wawancara bersama Bapak I Ketut Mustika Udaya, SH selaku notaris dan PPAT yang berkedudukan di kabupaten Tabanan yang dilaksanakan pada tanggal 27 Agustus tahun 2020 yang menjelaskan bahwa, beliau pernah menangani pembuatan suatu akta jaminan fidusia yang menggunakan kendaraan bermotor yang masih dalam proses inden sebagai jaminan. Syarat- syarat didalam pembuatan akta jaminan fidusia yang menggunakan kendaraan bermotor sebagai jaminan sama seperti syarat - syarat didalam membuat akta jaminan fidusia biasa. Menurut Bapak I Ketut Mustika Udaya, SH bahwa suatu kendaraan bermotor yang masih dalam proses inden bisa dibebankan dengan jaminan fidusia dengan menaati ketentuan yang telah ditetapkan, walaupun pada umumnya suatu kendaraan bermotor yang dibebankan dengan jaminan fidusia harus menyertakan BPKB yang mana nama yang tertera dalam BPKB harus sama dengan KTP dari pihak debitor tersebut. Pihak debitor yang ingin membeli suatu kendaraan bermotor namun terkendala dalam kepemilikan dana yang cukup untuk melakukan Down Payment atau lebih dikenal dengan istilah DP maka akan mendatangi pihak ketiga yaitu pihak Bank untuk memperoleh bantuan didalam melakukan proses DP hingga pembayaran pelunasan kendaraan bermotor tersebut. Pihak debitor dengan pihak bank akan membuat suatu perjanjian diantara mereka

\footnotetext{
12 Siringoringo, E. V., Dharmawan, N. K. S., \& Agung, I. G. N. (2010). Keabsahan Pendaftaran Fidusia Kendaraan Bermotor Secara Online Oleh PT. Federal International Finance Group (PT. FIF GROUP). h. 3

${ }^{13}$ Marulak Pardede. (2006). Implemetasi Jaminan Fidusia Dalam Pemberian Kredit Di Indonesia (Laporan Akhir Penelitian Hukum Badan Pembinaan Hukum Nasional Departemen Hukum dan HAM-RI, h. 54)
} 
mengenai tata cara pembayaran serta jangka waktu yang dipilih pihak debitor untuk melunasi utang yang dimilikinya.

Pembayaran DP untuk pembelian suatu kendaraan bermotor hingga pembayaran pelunasannya akan didanai oleh pihak Bank. Setelah dilakukannya pembayaran DP maka akan memperoleh suatu bukti pemesanan atau yang lebih dikenal dengan purchase order yang didalamnya berisi keterangan mengenai jenis kendaraan yang dibeli, harga dan nomor kerangka kendaraan bermotor. Bukti data pemesanan tersebut didalamnya akan tertera nama pihak debitor yang harus sama dengan KTP dari nama pihak yang akan membuat jaminian fidusia tersebut. Purchase order yang telah diterbitkan oleh pihak dealer akan dibawa oleh pihak bank ke kantor notaris untuk diperlihatkan dihadapan notaris serta di fotocopy sebagai arsip. Purchase order tersebutlah yang digunakan sebagai jaminan didalam pembuatan akta jaminan fidusia yang menggunakan kendaraan yang masih dalam proses inden sebagai pengganti dari BPKB. Menurut bapak I Ketut Mustika Udaya, SH menyatakan bahwa kedudukan purchase order dalam kasus ini sama seperti kedudukan BPKB yang digunakan sebagai jaminan didalam pembuatan suatu akta Jaminan fidusia. Setelah kendaraan yang di inden tersebut datang maka pihak bank yang akan melakukan pelunasan pembayaran kendaraan tersebut yangmana surat keterangan pembayaran lunas kendaraan tersebut harus dipaparkan dihadapan notaris. Ketentuan lain yang juga harus dipatuhi oleh pihak debitor adalah pihak debitor harus membuat suatu surat pernyataan sendiri yang isi dari perny ataan tersebut mengenai keharusan dari pihak debitor untuk menyerahkan BPKB kepada pihak bank saat BPKB tersebut telah terbit.

\subsection{Keabsahan Dari Suatu Akta Jaminan Fidusia yang Menggunakan Kendaraan Bermotor Yang Masih Dalam Proses Inden Sebagai Jaminan}

Notaris menurut ketentuan yang ada dalam Pasal 1 angka 1 Undang - Undang tentang Jabatan Notaris merupakan pejabat umum yang memiliki suatu kewenangan untuk dapat membuat suatu akta yang bersifat autentik serta memiliki kewenangan yang lainnya sebagaimana yang dimaksud didalam Undang - Undang ini. Menurut ketentuan dalam pasal 1868 KUHPerdata yang menentukan akta autentik haruslah dibuat didalam bentuk yang telah ditetapkan Undang - Undang serta dibuatnya dihadapan pejabat yang memang berkuasa dimana akta tersebut dibuat. Ketentuan pasal 2868 KUHPerdata tersebut menunjuk notaris lah yang dapat membuat akta autentik tersebut sesuai ketentuan dalam Pasal 1 angka 1 Undang - Undang tentang jabatan notaris. Notaris yang merupakan pejabat umum memiliki tanggung jawab terhadap akta yang telah dibuatnya. Akta autentik yang dibuat oleh notaris apabila memiliki suatu cacat hukum yangmana disebabkan oleh kelalaian pihak notaris maka harus diberikannya suatu bentuk pertanggungjawaban dari pihak notaris.

Notaris didalam melakukan upaya pencegahan dari terjeratnya didalam masalah hukum maka didalam membuat suatu akta harus menerapkan suatu prinsip kehati hatian seperti melakukan suatu pengenalan pada pihak penghadap serta identitas penghadap, melakukan verifikasi dengan cermat terhadap data subyek amupun obyek pihak penghadap, notaris memberikan masa tenggang waktu didalam proses pengerjaan akta autentik, bertindak secara hati - hati serta teliti didalam proses 
pembuatan suatu akta serta wajib memenhi segala persyaratan teknik didalam pembuatan suatu akta notaris. ${ }^{14}$

Didalam membuat perjanjian kredit yang menggunakan jaminan fidusia adanya suatu aspek penting yang sudah diatur didalam melakukan pengikatan kredit dengan jaminan fidusia pihak notaris haruslah memperhatikan hal - hal seperti semua barang yang dibebankan dengan suatu jaminan fidusia haruslah dijelaskan dengan jelas jenis kendaraan bermotor, jumlahnya, nilai kendaraan bermotor tersebut serta tanggal kepimilikan kendaraan bermotor tersebut yang dapat dilihat dari faktur, kwitansi maupun perjanjian jual beli serta tanggal pengikatan akta jaminan fidusia tersebut. Selain hal itu adanya aspek penting lainnya yang menentukan untuk sahnya suatu perjanjian fidusia antara lainnya :

1) Bukti kepemilikan atas barang tersebut adalah merupakan hal yang utama dan sangat penting untuk dapat membuktikan bukti kepemilikan atas barang yang dibebankan dengan suatu jaminan fidusia tersebut. Bukti kepemilikan atas barang yang dibebankan dengan jaminan fidusia harus diberikan kepada pihak bank untuk dikuasai oleh pihak bank agar dapat mencegah terjadinya tindakan dari pihak debitor yang ingin menjaminkan kembali benda tersebut kepada bank lainnya.

2) Adanya pengaturan terhadap masing - masing hak serta kewajiban dari para pihak.

3) Adanya standar yang ditetapkan untuk syarat - syarat perjanjian kredit adalah didalam menentukan sahnya suatu perjanjian yang dibuat serta agar perjanjian yang dibuat memiliki kekuatan hukum maka haruslah memenuhi syarat dari sahnya suatu perjanjian yang ditentukan dalam pasal 1320 KUHPerdata, perjanjian yang dibuat tersebut telah ditandatangani oleh pihak yang memang memiliki kewenangan serta dilakukannya pengikatan jaminan fidusia dalam bentuk notariil

4) Hak preferen diberlakukan bagi pihak kreditor lainnyaa adalah selain diberikannya hak preferen bagi penerima fidusia, undang - undang tentang jaminan fidusia juga menentukan diberikannya perlindungan lain untuk pihak bank dan pihak kreditor terhadap pihak ketiga. ${ }^{15}$

Kendaraan yang masih dalam proses inden merupakan pembelian suatu kendaraan yang dilakukan dengan cara memesan serta dilakukannya pembayaran terlebih dahulu yang dikenal dengan istilah $\mathrm{Dp}$ atau deposit payment. Hal tersebut berarti bahwa kendaraan yang dipesan oleh pihak pembeli belum ada maupun kendaraan itu sudah ada namun belum didalam penguasaan pihak dealer. Pembelian kendaraan yang masih dalam proses inden bisa dilakukan baik secara cash maupun kredit. ${ }^{16}$ Setelah dilakukannya pembayaran DP pada kendaraan inden tersebut yang dilakukan oleh pihak bank maka akan dikeluarkannya purchase order atas nama pihak pembeli

\footnotetext{
${ }^{14}$ Manuaba, I. B. P., Parsa, I. W., \& Ariawan, I. G. K. (2018). Prinsip Kehati-Hatian Notaris Dalam Membuat Akta Autentik. Acta Comitas, 59-74. h.10

${ }^{15}$ Paparang, F. (2014). Implementasi Jaminan Fidusia Dalam Pemberian Kredit Di Indonesia. Jurnal LPPM Bidang EkoSosBudKum, 1(2), 56-70. h.61

${ }^{16}$ Demoria Triyanthi Arios. 2018. Pertanggunjawaban Pihak Penjual atas Wanprestasi Dalam Pelaksanaan Perjanjian Jual Beli Mobil Dengan Sistem Inden Pada Dealer Mobil (Studi pada PT. Astra Internasional Auto 2000 Medan). (Program Kekhususan Hukum Perdata BW Universitas Sumatra Utara, h. 62)
} 
atau pihak debitor oleh pihak dealer. Purchase order merupakan surat bukti akan kepemilikan suatu kendaraan bermotor yang dimiliki oleh pihak debitor. Surat bukti kepemilikan suatu kendaraan bermotor didalam undang - undang jaminan fidusia dapat dibebankan dengan jaminan fidusia.

Keabsahan dari suatu akta autentik merupakan suatu hal yang penting dikarenakan adanya kepentingan antar para pihak dengan pihak notaris sendiri serta akta autentik tersebut sebagai alat bukti yang memang memiliki kekuatan pembuktian yang sempurna. Keabsahan dari suatu akta jaminan fidusia yang menggunakan kendaraan bermotor yang masih dalam proses inden sebagai jaminan dapat dilihat dalam ketentuan penjelasan Pasal 6 huruf c UU Jaminan Fidusia. Menurut ketentuan penjelasan pasal 6 huruf c UU Jaminan Fidusia tersebut hanya menyatakan bahwa suatu benda untuk dapat menjadi objek jaminan fidusia sudah cukup dengan hanya melakukan identifikasi terhadap benda tersebut serta dijelaskan dengan bukti yang dapat menunjukan kepemilikan terhadap benda tersebut. Ketentuan penjalasan Pasal 6 huruf $\mathrm{c}$ tersebut tidak menyatakan secara jelas harus menyertakan surat bukti kepemilikan yang berupa kepemilikan BPKB. Hal tersebut mengakibatkan kepemilikan purchase order atau bukti pemesanan suatu kendaraan bermotor yang masih dalam proses inden yang dimiliki oleh pihak debitor dapat digunakan sebagai surat bukti akan kepemilikan suatu kendaraan bermotor yang dapat digunakan sebagai jaminan dalam pembuatan akta jaminan fidusia.

\section{Kesimpulan}

Sesuai dengan hasil penelitian yang telah dilakukan, proses didalam pembuatan suatu akta jaminan fidusia yang menggunakan kendaraan bermotor yang masih dalam proses inden sebagai jaminan sama seperti proses didalam pembuatan suatu akta jaminan fidusia pada umumnya, namun adanya beberapa hal lain yang telah ditentukan yang harus dipatuhi oleh pihak debitor. Setelah dilakukan pembayaran awal atau Down Payment (DP) oleh pihak bank maka akan diterbitkannya purchase order oleh pihak dealer. Purchase Order nantinya akan digunakan sebagai jaminan yang akan dibawa oleh pihak bank dan akan diperlihatkan dihadapan notaris untuk diproses dalam pembuatan akta jaminan fidusia. Saat kendaraan yang masih dalam proses inden telah datang maka segera dilakukannya pelunasan oleh pihak bank serta bukti dari surat keterangan lunas tersebut harus dipaparkan dihadapan notaris. Pihak debitor juga harus membuat suatu surat pernyataan yang menyatakan untuk menyerahkan BPKB saat sudah terbit untuk diserahkan kepada pihak bank. Keabsahan dari suatu akta jaminan fidusia yang menggunakan kendaraan bermotor yang masih dalam proses inden sebagai alat bukti didalam ketentuan penjelasan Pasal 6 huruf c UU Jaminan Fidusia hanya menentukan suatu benda yang dijadikan objek jaminan fidusia harus dijelaskan mengenai surat bukti kepemilikannya yang tidak secara jelas ditentukan harus adanya kepemilikan BPKB sehingga bukti purchase order saja diperbolehkan sebagai bukti suatu kepemilikan kendaraan yang masih dalam proses inden. 


\section{Daftar Pustaka}

\section{$\underline{\text { Buku- Buku }}$}

Adjie, Habib. (2008). Hukum Notaris Indonesia (Tafsir Telematik Terhadap UU Nomor 30 Tentang Jabatan Notaris). Jakarta: Refika Aditama

Poerwadarminta W.J.S. (2007). Kamus Umum Bahasa Indonesia. Jakarta. PN. Balai Pustaka

Soekanto, Soerjono. (2012). Pengantar penelitian Hukum. Jakarta: UI Press

Usman, Rachmadi. (2009). Hukum Jaminan Keperdataan. Jakarta: Sinar Grafika

\section{Jurnal}

Hayati, N. (2016). Aspek Hukum Pendaftaran Jaminan Fidusia Berdasarkan UndangUndang Nomor 42 Tahun 1999 Tentang Jaminan Fidusia. Lex Jurnalica, 13(2), 147577.

Kumaladewi, N.A. (2015). Eksekusi Kendaraan Bermotor Sebagai Jaminan Fidusia yang Berada Pada Pihak Ketiga. Repertorium, 2(2).

Manuaba, I. B. P., Parsa, I. W., \& Ariawan, I. G. K. (2018). Prinsip Kehati-Hatian Notaris Dalam Membuat Akta Autentik. Acta Comitas, 59-74

Marulak Pardede. (2006). Implemetasi Jaminan Fidusia Dalam Pemberian Kredit Di Indonesia (Laporan Akhir Penelitian Hukum Badan Pembinaan Hukum Nasional Departemen Hukum dan HAM-RI)

Paparang, F. (2014). Implementasi Jaminan Fidusia Dalam Pemberian Kredit Di Indonesia. Jurnal LPPM Bidang EkoSosBudKum, 1(2), 56-70

Siringoringo, E. V., Dharmawan, N. K. S., \& Agung, I. G. N. (2010). Keabsahan Pendaftaran Fidusia Kendaraan Bermotor Secara Online Oleh PT. Federal International Finance Group (PT. FIF GROUP).

Widyari, I. A. M., Sirtha, I. N., \& Sarjana, I. M. (2017). Akibat Hukum Pendaftaran Jaminan Fidusia Dalam Sistem Online. Acta Comitas: Jurnal Hukum Kenotariatan, 2(2), 268-276.

Winarno, J. (2013). Perlindungan Hukum bagi Kreditur pada Perjanjian Jaminan Fidusia. Jurnal Independent, 1(1)

\section{$\underline{\text { Tesis/Disertasi }}$}

Demoria Triyanthi Arios. (2018). Pertanggungjawaban Pihak Penjual atas Wanprestasi Dalam Pelaksanaan Perjanjian Jual Beli Mobil Dengan Sistem Inden Pada Dealer Mobil (Studi pada PT. Astra Internasional Auto 2000 Medan). Universitas Sumatra Utara 
Sri Hartini. (2008). Pelaksanaan Perjanjian Kredit Dengan Jaminan Fidusia Di Kantor Pusat PT Bank Bukopin Tbk Jakarta. Universitas Diponegoro

\section{Peraturan Perundang-Undangan}

Kitab Undang - Undang Hukum Perdata (Burgelijk Wetboek)

Undang - Undang Nomor 42 Tahun 1999 tentang Jaminan Fidusia, Lembaran Negara Republik Indonesia Tahun 1999 Nomor 168, Tambahan Lembaran Negara Republik Indonesia Nomor 3889

Undang-Undang Nomor 2 Tahun 2014 tentang Perubahan atas Undang-Undang Nomor 30 Tahun 2004 tentang Jabatan Notaris, Lembaran Negara Republik Indonesia Tahun 2004 Nomor 117, Tambahan Lembaran Negara Republik Indonesia Nomor 4432 